\title{
Serbien rakastamisen sietämättömyys ja keveys
}

Minulta usein kysytään, miten olen päätynyt Serbiaan lampaankasvattajaksi. Se on pitkä tarina, jota harva jaksaa kuunnella alusta loppuun, ainakaan täällä Balkanilla. Useimmille riittää syyksi rakkaus, ja siihen kaikki toki kiteytyykin. Serbiassa rakastetaan rakkaustarinoita, joissa ulkomaalainen menettää sydämensä jollekin paikalliselle komistukselle tai kaunottarelle ja ihastuu sitä myöten myös maahan ja kansaan. Jos vielä päätyy tänne asumaan, on uutiskynnys ylitetty. Minun ja Jugoslavian tarina alkaa kuitenkin kauempaa, kauan ennen kuin nuori serbiupseeri sai vastoin kaikkea todennäköisyyttä valloitettua rauhankoulujakin pitäneen suomalaisen toimittajan ja Balkanin tutkimuksen opiskelijan sydämen.

Suhteeni Jugoslaviaan on mutkikas kuin musta kissa, mutta niin se on monella muullakin. Rakastaa ja vihata yhtä aikaa omaa maatansa ja kansaansa (tai niitä kaikkia päällekkäisiä) - sen tuntee moni entisen Jugoslavian perillinen. Siihen soppaan minäkin sieluni sujautin, mutta ilman mitään juuria tai taustaa Kaakkois-Euroopassa. Ihastuksesta ja vihastuksesta saa osansa eniten Serbia, se kun sattuu olemaan tässä silmäin alla. Tämä maa on toinen kotimaani, joka on adoptoinut minut avosylin. Tämä kansa on minun kansani, vieras ja tuttu, mutten voi sulkea silmiäni sen pimeiltä puolilta.

Ensimmäisen kerran tulin Jugoslaviaan interreilaten, reppu selässä syksyllä 1997. Halusin nähdä nimenomaan itäistä Eurooppaa, ja Jugoslavia kuulosti jännittävältä. Bosnian sodasta oli vain tovi, olin parikymppinen toimittajanalku ja minua kiinnosti nähdä uutisten taakse. Belgrad teki heti vaikutuksen. Se oli erilainen kuin muut kaupungit, ja jollain merkillisellä tavalla koin olevani kuin kotona. Monet muutkin ovat tunnistaneet sen, Balkanin tenhon. Siitä lähtien olen astellut entisen Jugoslavian kamaralla joka ikinen vuosi, yli puolet elämästäni. Balkanilainen vieraanvaraisuus, iloisuus ja auttavaisuus tekivät vaikutuksen matkoillani ja lämmittävät sydäntä edelleen. Täällä on helppo kokea olevansa tervetullut. Maahanmuuttajaa jopa kiitellään. Näin kävi kerran, kun tuntematon vanhempi mies arvuutteli, mistä olen ja mitä kieltä puhun. "Kiitos. Kiitos, kun asutte täällä", hän sanoi, kun kuuli, mistä olen kotoisin. Otin kiitokset vastaan muitta mutkitta, ja vasta myöhemmin mietin, olenko itse ikinä sanonut kenellekään ulkomaalaiselle niin Suomessa. Ja siinä on se rakkaus, minkä tähden Serbiassa on niin mukavaa asua. En voi väittää, että niin olisi jokaisella ulkomaalaisella. Ehkä olen vain onnekas ja osunut mukavien ihmisten pariin. Oli miten oli, en ole ainut, johon Serbia ja serbit ovat tehneet lähtemättömän vaikutuksen. 
Rakastan sitä keveyttä ja iloa, jolla täällä suhtaudutaan elämään, vaikka samalla kaiken yllä roikkuu jokin raskaus ja vaiva, muka. Rakastan balkanilaista spontaaniutta, vaikka se hengästyttää ja tuskastuttaakin suunnitelmallisuuteen tottuneen suomalaisen. Täällä ollaan yhtä aikaa jämähtäneitä ja äärimmäisen dynaamisia, luovia ja perinteisiin jumittuneita. Balkan on tynnyri täynnä ristiriitoja ja siihen voi ihastua ja turhautua yhä uudestaan ja uudestaan. Toisaalta, ilman rakkautta tuskin jaksaisin hengittää joka talvi savusumua, joka piinaa lämmityskaudella kaupunkiamme. Kohdata korruptiota, joka luikertelee vastaan aina siellä, missä jotain järkevää ja hyvää voisi saada aikaan. Ilman rakkautta en viitsisi sietää sitä huijausten ja vilpin määrää, joka lyö ällikällä. Enkä varsinkaan itsesäälissä rypevää nationalismia ja kansallismielistä öyhötystä, joka saa pontta jostain uhriuden ja syyllisyyden, ylpeyden ja alemmuuden merkillisestä vyyhdestä. Ilman rakkautta saattaisin olla nytkin mieluummin järkevästi ja reilusti organisoidussa kotimaassani kuin salaliittoteorioiden ja koronan kurittamalla Balkanilla.

Saksalais-sveitsiläinen kriminologian uranuurtaja Rodolphe Archibald Reiss (1875-1929) eli nähtävästi vastaavien mietteiden äärellä Belgradissa sata vuotta sitten. Hän purki turhautumisensa pamflettikirjaan, joka julkaistiin vasta 2004 nimellä Čujte Srbi! Čuvajte se sebe (Kuulkaa, serbit! Varokaa itseänne). Reissin teräväkynäinen kansanluonneanalyysi on ollut Serbiassa suosittu, mutta tuskin olisi herättänyt kiitosta kirjoittajan elinaikana. Omalla kohdallani tuskaa lisää paitsi akateemiset opinnot myös se, etten oikeastaan päätynyt tänne Pohjolasta, vaan Bosniasta. Kun katson ikkunastani länteen kohti vuoria, ajattelen bosnialaisia ystäviäni, jotka menettivät kotinsa ja useita läheisiään Drina-joen toisella puolen. Siitä ei monikaan täällä halua kuulla. Srebrenican kansanmurha on häiritsevä piikki serbien sankaruudessa ja uhriudessa, ja on piinallista seurata sen aiheuttamaa kiemurtelua.

Vaikka tulin ensimmäiseksi juuri Serbiaan, aivan erityisesti rakastuin Bosniaan, sillä siellä kaikki tiivistyy. Olin nähnyt uutisissa sotaa ja vihaa, mutta paikan päällä kohtasinkin rakkautta ja välittämistä. Samalla sodan rauniot muistuttivat siitä, että vasta hetki sitten juuri täällä oli tapahtunut mitä suurimpia hirveyksiä. Ennen pitkää minulle kävi juuri niin kuin Maria Todorova kirjoitti länsimaalaisista 1990-luvulla: projisoin omat ongelmani Balkaniin. Jugoslavian tarina oli minun tarinani, se peili, jota katsoin, jotta ymmärtäisin itseäni ja pakenisin itseäni. Sellaista ihmisen rakkaus on, harvemmin täysin pyyteetöntä ja puhdasta.

Mutta vaikka se rakkaus ei ole täydellistä, ei sen enempää minun antamani kuin saamanikaan, on kumpikin totta. Archibald Reissin sanoin, kiinnymme ihmisiin ja asioihin niin vahvasti kuin se kiintymys meille maksaa uhrautumista. Pidän etuoikeutena asua juuri Serbiassa, kirjaimellisesti ruohonjuuritasolla, tämän erikoisen ja historian mukiloiman kansan syvien rivien keskellä. Serbia opettaa keskeneräisyyden sietokykyä ja sitä, että elämästä voi nauttia, vaikka asiat olisivat epävarmoja ja rempallaan. Balkan opettaa myös sitä, että ihminen on kuin lammas - menee joukon mukana, tarvitsee hyvää paimenta, eikä ole onnellinen yksinään.

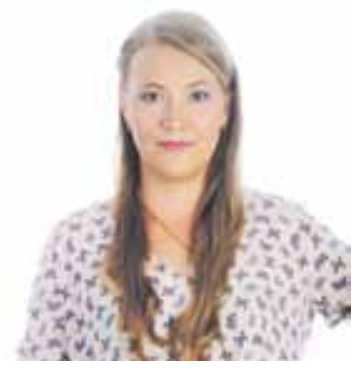

Mia Tadić

Kirjoittaja on Serbiassa asuva toimittaja, filosofian maisteri ja lampaankasvattaja. 